\title{
Students' Perception to the Use of Indirect Corrective Feedback in Writing Recount Text
}

\author{
${ }^{* 1}$ Endah Anisa Rahma, ${ }^{2}$ Siti Sarah Fitriani, ${ }^{1}$ Rina Syafitri \\ ${ }^{* 1}$ Universitas Teuku Umar, Indonesia \\ ${ }^{2}$ Universitas Syiah Kuala, Indonesia \\ *Corresponding Author: endahanisarahma@utu.ac.id
}

\author{
Submitted: 22/04/2020 Revised: 12/05/2020 Accepted: 19/05/2020
}

How to cite this article: Rahma, E. A., Fitriani, S.S., \& Syafitri, R. (2020). Students' perception to the use of indirect corrective feedback in writing recount text. IJELR: International Journal of Education, Language, and Religion, 2(1), 25-30. https://doi.org/10.35308/ijelr.v2i1.2222

\begin{abstract}
Providing written corrective feedback is a necessity to help language learner improve accuracy. This research aims to seek out students' response toward the use of Indirect Corrective Feedback to reduce error on students' recount text. Tenth graders of SMAN 1 Meulaboh were the sample of this study and observed during the correction. Data from the close-ended questionnaire was analyzed qualitatively and were calculated using percentage system. The result showed that most students agreed about the implementation of Indirect Corrective Feedback and they believe that this error correction strategy helps them to reduce errors in writing recount text. The result confirm that the students responded positively toward the use of Indirect Corrective Feedback.
\end{abstract}

\section{Keywords}

Writing; Indirect Corrective Feedback; Errors; Recount Text

\section{Introduction}

Writing is one of skills that needs to be learned by the students. An ability to write in English language is important for English language learners, particularly in the context of English as a Foreign Language. Through writing, English language learners are able to convey messages to the readers across place and time. Writing skills are language skills that are difficult and complex because it requires a wide of insight and extensive thinking. It can be said that writing involves several components including contents, organizations, vocabularies, grammatical structures, and mechanics such as punctuation and capitalization. Consequently, students are not able to write due to writing they do not master these components. It means, when writing, students need to express ideas and arrange the ideas in a good content, organization, vocabulary, grammar, and mechanic.

Writing involves producing words and sentences. Therefore, writers should be able to write a series of connected words and sentences which are grammatically and logically linked so that the purpose of writers' mind will suit to the readers' intention. In line with the statement, Harfield (1985) cited in 
Muktamien (2007) explains that to make a good writing, writer do not only express the ideas into written form, but they also have to write in acceptable written language and under writers' linguistic and communicative competence.

Writing is considered as a complex skill in teaching and learning process (Widiyati \& Cahyono, 2006). Furthermore, Richard and Renandya (2002) also agreed that writing is a difficult skill for second and foreign language learners to master since writing requires cognitive analysis to pattern the language in order to be able to convey ideas, messages, and feeling to the readers. Cognitive analysis involves thinking process when the writers organize the composition. The process is generally operated in four processes; pre-writing, planning, writing, editing (Oshima \& Hogue, 2000, p. 4). Those processes help the learners to produce a good writing both accuracy, cohesive and coherence. Celce-Murcia (2001) stated that grammatical accuracy plays important role in writing since the most errors committed by learners are grammatical errors. She also added that the writing processes lead the second or foreign language learners to express idea with coherence and accuracy. This statement means that a writing will be meaningful if it has grammatical accuracy aspect.

English foreign students commonly face problems in grammatical aspects particularly in forming verb, noun and word (Rahma \& Fitriani, 2016). Students' errors that indicated include, for example, incorrect verb tense. One student wrote, "Last week, we gather and visit bookstore". The sentence should actually be written in past verb form, gathered and visited. Verb error deals with all errors in verb tense, verb form and relevant subject-verb agreement error. Another example can be seen in this sentence, "Last holiday, I went to my aunt house". The sentence has incorrect noun ending since the student did not put possessive mark. It should be in possessive form like this, "aunt's house". Noun error relates to all error in plural mark and possessive ending

The grammatical accuracy could be measured by error correction. Corrective feedback is also known as error correction on grammar correction is written on the writing assessment (Ferris, 2011). Using corrective feedback helps the learners to improve students' grammatical accuracy (Ferris, 2003). Giving feedback to foreign language learners both during and after learning task are key elements in error correction process (Zamel, 1985). Ideally, students who wish to compose well in writing need to help in understanding and avoiding mistake in their writing since they need ways to know whether they are on track or not. Corrective feedback is a fundamental element of process approach to writing. It can be defined as an input from readers to writers by providing information for revision. The error correction can be done by providing correction symbol or by locating the error that is called Indirect Corrective Feedback (Ferris, 2003).

Indirect Corrective Feedback (ICF) is provided when the teacher only refers to the location of the student's errors on the paper by underlining, highlighting or circling, or by indicating the error code to indicate, without providing any correct form (Lee, 2004). From the definition, it can be stated that teachers only indicate the errors, but do not provide any correction; and students themselves are required both to identify the type of errors and to correct them. ICF is done by indicating an error by underlining or using the error code (Ferris, Chaney, Komura, Robert, \& McKee, 2000). Indirect corrective feedback involves indicating the students' error without actually correcting it. This can be done by underlining the errors or using cursor to show the omission in the student's text (Ellis, 2009). Indirect feedback indicates some ways in errors that have been made by students without explicitly mentioning the type of error or providing the correct form (Ferris, 2003). This is the example of ICF with code that is applied on students' writing: 


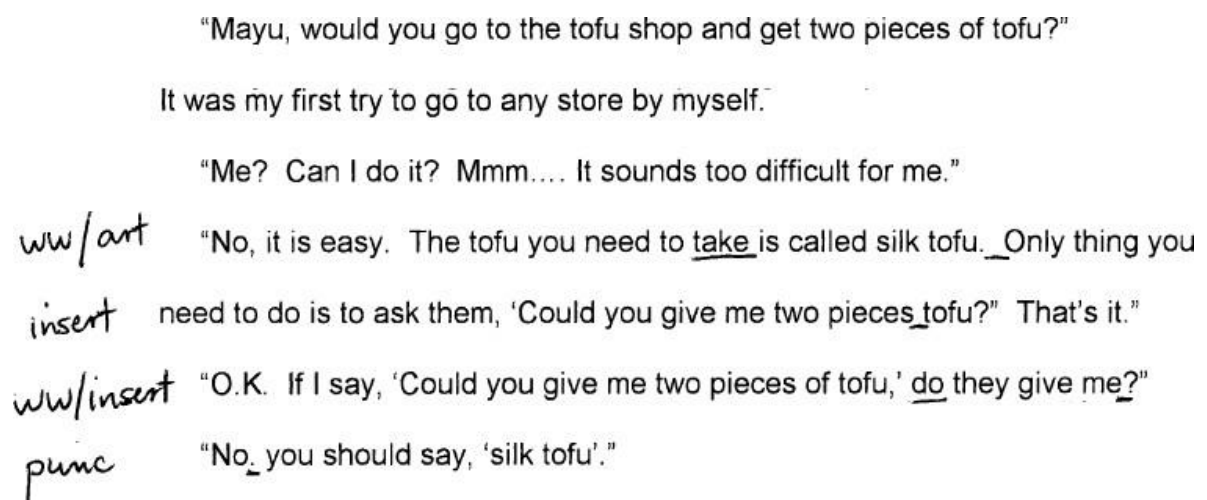

Figure 1: Underlining and Describing/Code (Chandler, p. 283)

Previous study conducted by Rahma and Fitriani (2016) found that the implementation of Indirect Corrective Feedback reduced the students' errors in writing. The students who are given Indirect Corrective Feedback improve their achievement in writing in terms of grammatical errors: verb, noun ending, word form, word order, spelling, pronoun, conjunction, missing and unnecessary word, compared to students who are not given this type of correction feedback. It was proven by the t-test of post-test score of both groups which is higher than t-table $(1.823>1.68)$. According to the study, verb error aspect is the most dominant decrease among other aspects. Although verb aspect was the dominant error, the students were able to minimize the error on post-test. This is because they remembered the use of past verb in recount text when the teacher explained the grammatical features of the text in the beginning of treatment.

Based the theoretical background above, the writer is interested in seeking out the students' response towards the use of Indirect Corrective Feedback in assessing their grammatical errors in writing recount text for Senior High School students. In addition, study about corrective feedback for Senior High School is still limited in Indonesia. Thus, the focus of this study is the effectiveness of Indirect Corrective in improving grammatical accuracy of students' recount text.

\section{Method}

This is qualitative study. The data were taken from questionnaire. In this study, researcher used closeended question. The question consisted of 6 questions with 5 point scales; Strongly Agree (5), Agree (4), Neutral (3), Disagree (2), and Strongly Disagree (1). The questionnaire was distributed to 30 tenth graders of SMAN 1 Meulaboh. This questionnaire was adapted from thesis written by Najmaddin (2010). The result of questionnaire was analyzed by percentage of students' response. To count the percentage of the question, the researcher uses the formula:

Where,

$$
P=\frac{\mathrm{F}}{\mathrm{N}} \times 100 \%
$$

$$
\begin{array}{ll}
\mathrm{P} & \text { : Questionnaire percentage } \\
\mathrm{F} & : \text { Frequency } \\
\mathrm{N} & \text { : Total of respondent }
\end{array}
$$

(Sudijono, 2006) 


\section{Results and Discussion}

The result from questionnaire is presented briefly here. The writers explain the questionnaire per each item. The result of questionnaire is in the following chart:

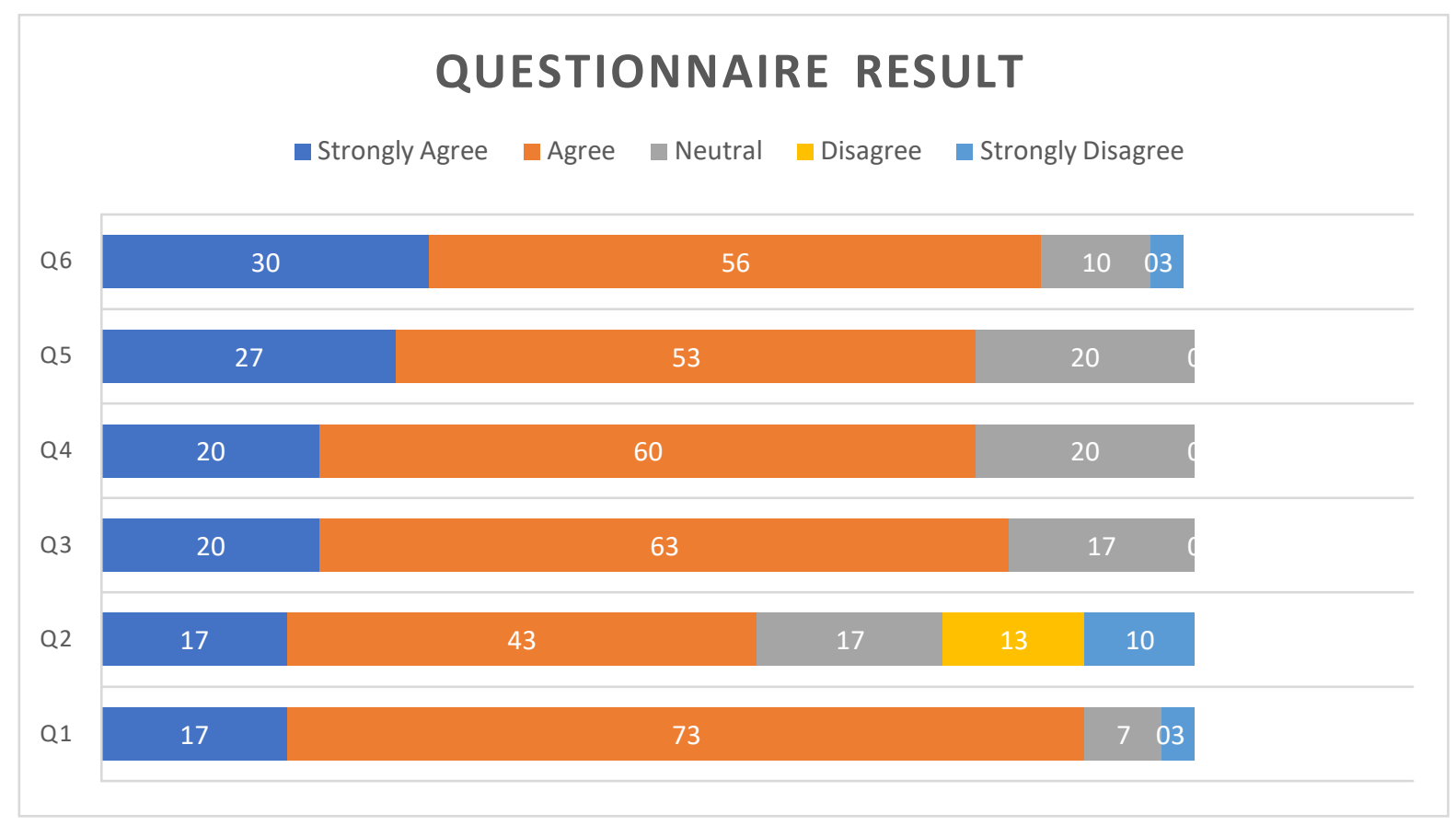

\section{Chart 1. Result from Questionnaire}

From the statement number one "I can understand what to do to correct my errors in writing recount text by using indirect corrective feedback technique', it can be seen that as many as $17 \%$ students strongly agreed the statement. Meanwhile, 73\% students agreed to the statements. However, there were $7 \%$ of them chose neutral or undecided while $3 \%$ disagreed. It can be implied that they understand how to correct their error in writing recount text by the use of indirect corrective Feedback. Students comprehend well to correct errors in recount text.

The second item of questionnaire is about "I think indirect corrective feedback encourage me in writing recount text". Mostly as much as $43 \%$ students agreed to the statements. For the third statement, mostly $63 \%$ of the students agreed that indirect corrective feedback help them to develop the use of language features of recount text that related to error category. It can be seen that students who chose strongly agree was almost same with who chose neutral. It was inferred that not all students are able to develop the use of language features of recount text that related to error category even though most of them are able to use the language features. Based on study from Rahma and Fitriani (2016), the progress in writing accuracy is indicated from the reduction of error frequency experimental group students made in posttest. Hence, Indirect Corrective Feedback improves students' ability to evaluate their own composition. In the treatments, students were given clues by the teacher by providing different codes for different error aspects. Thereafter, they corrected the errors and revised their writing. This process helped students to improve writing.

Next, statement number 4, $20 \%$ of the students strongly agreed and $60 \%$ of the students agreed that Indirect Corrective Feedback minimizes their error in writing although $20 \%$ of them chose neutral. It was revealed that the students enabled to reduce their errors after given Indirect Corrective Feedback. According to Reid (1982, p.167) verb tenses and verb tense agreement are often problems for ESL or EFL writers. Rules for the use of verb tenses are so various and often so complex that frequently second language errors occur. While verb form occurred fewer than verb tense since some of the students knew the rule of formation of verb. 
For statement number 5, it was $80 \%$ of students considered Indirect Corrective Feedback encouraged them to write the sequent events based on the generic structure of a recount text; however $20 \%$ of them chose neutral. Indirect Corrective Feedback helps them to write the recount text sequently. Recount text has three main parts; orientation, events, re-orientation. It can be proven when the learners in revision stage, they were introduced the generic structure by their teacher (Rahma \& Fitriani, 2016).

The last statement, as many as $30 \%$ of students strongly agreed and $56 \%$ of them agreed that they would remember their errors and avoid making the errors in the future. Only $3 \%$ of students disagree about the statement. It means that most students will remember and avoid the errors. Some studies related to error corrections in students writing have reported that Indirect Corrective Feedback is beneficial in helping students to make progress in accuracy over time (Ferris et al, 2000) as well as improving their ability to edit their own composition (Chandler, 2003; Ferris \&Robert, 2001; Lalande, 1982; Lee, 1997). Providing students with Indirect Error Corrective Feedback on categories of error is capable helping them to focus their attention on the grammatical errors marked by the teacher and try to learn how to self-edit and finally overcome these grammatical errors in the later revision of their written text (Noroozizadeh, 2009). Students at lower level of L2 proficiency may need and be helped by an indication the error types, not only to correct the error in a particular text, but also to help process real-world language use (Ferris, 2011, p.151).

From the result of questionnaire above, it can be concluded that most students agreed about the implementation of indirect corrective feedback in reducing error on students' writing. The students respond positively toward Indirect Corrective Feedback.

Based on the data from the questionnaire, it can be concluded that students react positively to the strategy of Indirect Corrective feedback. It was proven from most students agree with the implementation of Indirect Corrective Feedback and they believed that the error correction strategy help them to reduce error in writing recount text. It is supported by the finding from Ferris and Robert (2001) and Ferris and Hegdcock (2005) about students' preference for corrective feedback. The students agreed that Indirect Corrective Feedback helps them in reducing error. Finding from Chandler's study (2003) shows that students also felt that they learnt more from Indirect Corrective Feedback because they could look up for the correct answer and remember the mistake they made so they did not make the same mistake for the next revision.

\section{Conclusion}

The result from many studies in literature review showed that the more feedback the students receive, the better they understand what they need to avoid or correct their error which result more effective writing. Besides, providing error correction also encourages the students to learn independently and read more their writing in order to become better writers. Based on the result from questionnaire, it can be concluded that students had the positive responses toward this error correction strategy. The finding of questionnaire revealed that Indirect Corrective Feedback improve their writing recount text ability, particularly in reducing the grammatical errors related to the grammatical features involved in recount text. They agreed that this strategy help them to be aware of the grammatical errors in writing a recount text.

\section{Acknowledgement}

We would like to acknowledge to all the participants who had contributed for this article including the chief editor for insightful suggestions. 


\section{References}

Celce-Murcia, M. 2001. Teaching English as a second and foreign language. London: Heinle \& Heinle

Ellis, R. 2009. A typology of written corrective feedback types. ELT Journal. 63, 97-107.

Ferris, D. R., Chaney., S. J., Komura, K., Robert, B. J., \& McKee, S. (2000). Perspective, problem, and practice in treating written error. In Colloqium Presented at International TESOL Covention, Vancouver, B.C. March 14-18.

Ferris, D., \& Robert, B. (2001). Error feedback in L2 writing classes: how explicit does it need to be? Journal of Second Language Writing. 10, 161-184.

Ferris, D. R. (2003). Response to writing: implication for second language students. Mahwah, NJ: Lawrence Erlbaum.

Lee, I. (2004). Error correction in L2 secondary writing classrooms: the case of Hong Kong. Journal of Second Language Writing. 13 (4), 285-312.

Muktamien. (2007). Interference in learning English: Grammatical errors in English essay writing among rural Malay secondary school students in Malaysia. Jurnal E-Bangi, (2) 2, 1-15.

Najmaddin, S. M.A. (2010). Teachers' and students' perception of type of corrective feedback in writing. Thesis. Bilkent University, Ankara. Retrieved $11^{\text {th }}$ April 2015, from: //http.www.thesis.bilken.edu.tr/0003965.pdf//

Oshima, A \& Hogue, A. (2000). Writing academic English. New York: Longman

Rahma, EA \& Fitriani, SS. (2016). The effect of indirect corrective feedbackin Reducing rrrors on students' writing. Proceeding of The $6^{\text {th }}$ Annual International Conference Syiah Kuala University (AIC Unsyiah) in conjunction with The $12^{\text {th }}$ International Conference on Mathematics, Statistics, and Its Application (ICMSA). Banda Aceh: 4-6 October 2016. Page 358-362.

Richard, J. C., \& Reinandya, W. A. (2002). Methodology in language teaching: an anthology of current practice. London: Cambridge University Press.

Sudijono, A. (2006). Pengantar statistik pendidikan. Jakarta : PT. Raja Grafindo.

Reid, J. M. (1982). The process of composistion. Englewood Cliff: Prentice Hall.

Widiyati, U., \& Cahyono, B. Y. (2006). The teaching of EFL writing in the Indonesian context. The State of The Art. Jurnal Ilmu Pendidikan. 13(03), 139-150.

Zamel, V. (1985). Responding to students writing. TESOL Quarterly. 19 (1), 77-101. 